\title{
EIMERIA (COCCIDIA: EIMERIDEA) OF HARES IN FrANCE: DESCRIPTION OF NEW TAXA
}

\author{
AOUTIL N.*, BERTANI S.*, BORDES F.*, SNOUNOU G.*, CHABAUD A.* \& LANDAU I.*
}

\section{Summary:}

The oocysts of coccidian of the genus Eimeria were sought in the caecal contents of 46 Lepus granatensis and 18 L. europaeus captured in France. Parasites were found in 34 of the hares. Parasite load was mainly very low. However, species diversity was considerable. 21 species or subspecies were identified, of which 13 species and two subspecies were not previously described. Three of the taxa, E. robertsoni, E. semisculpta and E. townsendi, previously identified on numerous occasions in western Europe and, corresponding to forms or variants created before 1960 that have been subsequently elevated to a specific level, appear to be invalid. Indeed, the parasite descriptions from the material used to effect this modification do not correspond to the original descriptions. A stable equilibrium, as generally observed in the case of many congeneric species co-infection of the same host, was not observed in the hares. This has been attributed to the solitary habits of the host and of the probable polyphyletic nature of the genus Eimeria. Paleontological data for the Leporidae indicate that rabbit parasites are derived from those of the hare.

KEY WORDS : Eimeria, Lepus europaeus, Lepus granatensis, France, new taxa, parasitological equilibrium.
Résumé : Eimeria (Coccidia: EIMERIDEA) DES LiÈvRes en France : DESCRIPTION DE NOUVEAUX TAXA

Les oocystes des coccidies du genre Eimeria ont été recherchés dans environ $2 \mathrm{~g}$ du contenu caecal de 46 Lepus granatensis et de $18 \mathrm{~L}$. europaeus en France. 34 sont parasités. Ils ont presque toujours une charge parasitaire très faible. La diversité spécifique est néanmoins considérable. 21 espèces ou sous espèces sont identifiées dont 13 espèces et deux sous espèces sont nouvelles. Trois des taxa identifiés plusieurs fois en Europe occidentale : E. robertsoni, E. semisculpta et E. townsendi, qui correspondent à des formes ou à des variétés créées avant 1960 et qui ont été élevées ultérieurement au niveau spécifique, nous semblent inutilisables. En effet, la description du matériel utilisé pour effectuer cette modification ne correspond pas à la description originale. Les équilibres stables constatés habituellement dans les cas de nombreuses espèces congénériques coexistant chez un même hôte ne sont pas retrouvés chez les lièvres. Cette exception est attribuée aux moeurs solitaires de l'hôte et au polyphylétisme très vraisemblable du genre Eimeria. Les données paléontologiques sur les Leporidés indiquent que les parasites des lapins dérivent de ceux du lièvre.

MOTS CLÉS : Eimeria, Lepus europaeus, Lepus granatensis, France, nouveaux taxa, équilibre parasitaire.

\section{INTRODUCTION}

A study of Eimeria in wild rabbits by Grès (2001) and Grès et al. (2003) have shown that a stability in the rank of prevalence of each parasite species became established, in spite of the opportunist feeding regimes of this rabbit and of the fragility of Eimeria oocysts, both factors favouring disequilibrium. Thus, irrespective of the geographical site, the season, or the age of the host, some species are consistently dominant while others are invariably rare. We felt it would be of interest to use the same techniques and criteria in a comparison with the coccidians

\footnotetext{
* Parasitologie Comparée et Modèles Expérimentaux, USM 0307, associated to INSERM U567, CNRS IFR101, and Laboratoire de Protozoologie et Parasitologie Comparée (EPHE), Muséum National d'Histoire Naturelle, CP52, 61, rue Buffon, 75231 Paris Cedex 05, France. Correspondence : Pr Irène Landau.

Tel.: 33 (0)1 407935 00/1 - Fax: 33 (0)1 40793499

E-mail: landau@mnhn.fr
}

of hares, a host that has distinct feeding habits to the wild rabbit.

\section{MATERIALS AND METHODS}

\section{ORIGIN OF THE BIOLOGICAL MATERIAL}

46 Lepus granatensis Rosenhauer, 1856 ( $\mathrm{N}^{\circ}: 1-11,13-$ $16,18-20,24-31,34-39,42,44-50,52,53,55-58)$ and nine L. europaeus Pallas, 1778 (12, 17, 32, 33, 40, 41, $43,54,59)$, were caught during September and October 2003 in the Pyrénées-Orientales, in areas most made up of vineyards: Claira, Rivesaltes, Cabestany, Canet and Thuir.

We also had access to L. europaeus samples from different regions: four animals (60-63) caught in October 2003 on cultivated land at Doulieu and at Estaires (Nord), four samples (64-67) from Vergies (Somme), also in October 2003, and finally one animal (68) from the Paris region, in January 2004. 


\section{METHODS}

$2 \mathrm{~g}$ of the caecal content were removed during autopsy and mixed with potassium dichromate (final concentration $2.5 \% \mathrm{v} / \mathrm{v}$ ) in a Petri dish and allowed to mature. The inventory of the parasites present in each dish was made following concentration by flotation in magnesium sulphate. The concentrates were stored at $4^{\circ} \mathrm{C}$ $8^{\circ} \mathrm{C}$ in a solution of potassium dichromate (final concentration $0.5 \% \mathrm{v} / \mathrm{v}$ ).

\section{DEFINITIONS AND ABBREVIATIONS}

Micropyle ring $=$ thickening of the external walls surrounding the micropyle, sometimes found jutting out. The diameter of the micropyle was measured within the ring.

$\mathrm{OR}=$ oocyst residuum; $\mathrm{SR}=$ sporocyst residuum; $\mathrm{SI}=$ shape index (length/width).

Oocyst shape: some confusion may arise as to the shape of the oocysts described in the litterature. Two definitions are given to the term ellipse in Webster's Dictionnary (1985): a) "oval"; b) "a closed plane curve generated by a point moving in such way that the sums of its distances from two fixed points is a constant'. We have followed the second definition when referring to an oocyst as ellipsoid $=$ oocyst with the two ends almost symetrical, whereas an oocyst is described as ovoid when the micropylar end is narrower than the opposite end.

\section{DESCRIPTIONS}

Units of measurements are all expressed in microns. All sporocysts possess a Stieda body, apparently similar between the species, and thus not further described in this study.

Details of the oocyst morphology for Eimeria of Oryctolagus, referred to in the discussion, are found in Coudert et al. (1995).

\section{TYPE MATERIAL}

Since it is not possible to obtain permanent oocyst preparations, we have designated as holotype material, numbered photos of the oocysts that have been deposited at the laboratory.

\section{NOMENCLATURE}

We have been faced with the following difficulties: the names of three forms or varieties described prior to 1960 had been redescribed and elevated to a specific rank at a later date. However, in all three cases this change of status was based on material originated from another host species collected in a different region, and furthermore the morphological descriptions did not adequately correspond with those provided in the ori- ginal descriptions. We have therefore considered the names given to the following three parasites as invalid: 1) E. magna forma townsendi Carvalho, 1943, elevated to the rank of species by Pellérdy in 1956, will be discussed in the section on E. tailliezi, 2) E. magna var. robertsoni Madsen, 1938, elevated to the rank of species by Carvalho in 1943, will be discussed in the section on E. coquelinae, and 3) E. magna var. robertsoni forma semisculpta Madsen, 1938, elevated to the rank of species by Pellérdy in 1956 will be discussed in the sections on E. pierrecouderti and E. tailliezi.

The keys of identification are given at the end of the descriptive part (Table I).

To simplify the nomenclature, all the new taxa described in this article are attributed to Aoutil \& Landau.

\begin{tabular}{|c|c|c|}
\hline $1-(8)$ & micropyle absent & \\
\hline 2-(7) & OR present & \\
\hline 3-(6) & SR present; ellipsoid oocyst & \\
\hline $4-(5)$ & $\mathrm{L}>30 \mu \mathrm{m} ; \mathrm{L} / \mathrm{l}>2$ & E. leporis leporis \\
\hline $5-(4)$ & $\mathrm{L}<30 \mu \mathrm{m} ; \mathrm{L} / \mathrm{l}=1.87$ & E. leporis brevis \\
\hline 6-(3) & SR absent; rounded oocyst & E. orbiculata \\
\hline $7-(2)$ & OR absent & E. audubonii \\
\hline 8-(1) & micropyle present & \\
\hline $9-(30)$ & OR present rounded & \\
\hline $10-(19)$ & SR present & \\
\hline 11-(16) & $\mathrm{L}>30 \mu \mathrm{m}$ & \\
\hline $12-(15)$ & smooth wall & \\
\hline 13-(14) & ellipsoid short; L/1 = 1.63 & E. europaea \\
\hline 14-(13) & ellipsoid long; $\mathrm{L} / \mathrm{l}=1.89$ & E. nicolegerae \\
\hline $15-(12)$ & granular wall; $\mathrm{L} / \mathrm{l}=1.39$ & E. gantieri \\
\hline $16-(11)$ & $\mathrm{L}<30 \mu \mathrm{m}$ & \\
\hline $17-(18)$ & ovoid long; $\mathrm{L} / \mathrm{l}=1.75$ & E. deharoi deharoi \\
\hline $18-(17)$ & ovoid short; $\mathrm{L} / \mathrm{l}=1.44$ & E. deharoi rotonda \\
\hline $19-(10)$ & SR absent & \\
\hline 20-(21) & $\mathrm{L} \leq 30 \mu \mathrm{m}$; whitish oocyst & E. bainae \\
\hline 21-(20) & $\begin{array}{l}\mathrm{L}>30 \mu \mathrm{m} \text {; yellowish or brownish } \\
\text { oocyst }\end{array}$ & \\
\hline $22-(25)$ & $\mathrm{L}<35 \mu \mathrm{m}$ & \\
\hline $23-(24)$ & ellipsoid; granular wall & E. coquelinae \\
\hline 24-(23) & ovoid; smooth wall & E. gresae \\
\hline $25-(22)$ & $\mathrm{L}>35 \mu \mathrm{m}$ & \\
\hline $26-(27)$ & rounded oocyst; $1>27 \mu \mathrm{m}$ & E. mazierae \\
\hline $27-(26)$ & more elongated oocyst; $1<27 \mu \mathrm{m}$ & \\
\hline 28-(29) & smooth wall & E. reniai \\
\hline $29-(28)$ & anterior granular wall & E. pierrecouderti \\
\hline 30-(9) & $\begin{array}{l}\text { OR absent or reduced to a few } \\
\text { granules }\end{array}$ & \\
\hline $31-(40)$ & SR present; $\mathrm{L}>30 \mu \mathrm{m}$ & \\
\hline $32-(37)$ & $\mathrm{L}<40 \mu \mathrm{m}$ & \\
\hline 33-(36) & smooth wall & \\
\hline $34-(35)$ & ovoid; L/1 = 1.59 & E. cabareti \\
\hline $35(34)$ & ellipsoid; L/1 = 1.73 & E. stiedai \\
\hline $36-(33)$ & entirely granular wall & E. lapierrei \\
\hline $37-(32)$ & $\mathrm{L}>40 \mu \mathrm{m}$ & \\
\hline $38-(39)$ & ellipsoid; $\mathrm{L} / \mathrm{l}=2.03$ & E. macrosculpta \\
\hline 39-(38) & ovoid; $\mathrm{L} / 1=1.83$ & E. tailliezi \\
\hline $40-(31)$ & SR absent; $\mathrm{L}<30 \mu \mathrm{m}$ & E. babatica \\
\hline
\end{tabular}

Table I. - Keys for identification; L = length; 1 = width. 


\section{MORPHOLOGICAL OBSERVATIONS}

1 - EIMERIA LEPORIS LEPORIS, NiESCHUlZ, 1923

(Figs 1.1 and 2.1)

Material studied: L. granatensis 10 (Fig. 1.1), 36, 45, 56 and 58.

Size: $33 \times 15 \mu \mathrm{m}(28-41 \times 15-19) ; \mathrm{n}=145 ; \mathrm{SI}=2.2$.

Shape and colour: ellipsoid elongated or slightly kidney-shaped, of a very pale yellow or white colour. Wall: thin and smooth with a flattened pole.

Micropyle: absent.

Sporocysts: these occupy $2 / 3$ of the oocyst, and are stocky, measuring $15 \times 8 \mu \mathrm{m}$, and sporozoites contain one large elongated refractile body.

Residua: a round small OR of $6 \mu \mathrm{m}$ in diameter is present, a well limited SR with fine grains is present.

\section{Discussion}

This species characteristic of Lepus has no equivalent in Oryctolagus or Sylvilagus. The original description of E. leporis, Nieschulz, 1923, in The Netherlands, corresponds by its dimensions and morphology to the E. leporis that we have encountered in France. This applied equally to the species described under the same name by Carvalho (1943) in L. townsendi campanius Hollister, 1915, captured in Iowa (USA).

In their publications, Pellérdy (1956; 1974) in Hungary, and Bouvier (1967) in Switzerland, described the oocysts as having an SR consisting of a few granules, whereas it was found to be round and compact by Nieschulz, Carvalho (1943) and us. In a study of this species in England, Robertson (1933) provides detailed measurements that indicated the existence of three peaks in the size histogram. A population of small parasites $(25.44 \times 14.37 \mu \mathrm{m})$; one of medium size $(31.47 \times 16.27 \mu \mathrm{m})$, and one of large size $(36.8 \times$ $18.4 \mu \mathrm{m})$.

Our observations in the hares 58 and 45 , revealed a gaussian type histogram with one peak at $27 \mu \mathrm{m}$ in length and $14 \mu \mathrm{m}$ in width $(\mathrm{n}=14$ for hare 58 and $\mathrm{n}=10$ for hare 45 ), thus corresponding to the small parasites above. Hare 36, harbouring a higher parasite load $(n=146)$, presented a non-gaussian histogram, that we are inclined to interpret as being the sum of two populations, one corresponding to the medium size species of Nieschulz $(33.3 \times 15.4 \mu \mathrm{m})$ and the other, found as a pure infection in hares 45 and 58 , to the small species $(27 \times 14 \mu \mathrm{m})$.

Taken all together these observations suggest to us the existence of two sub-species whose localisation in the host or whose biological cycles are distinct. We propose to designate them as follows: E. leporis leporis Nieschulz, 1923 and E. leporis brevis n. subsp. described below.
2 - E. LEPORIS BREVIS N. SUBSP. AOUTIL \& LANDAU (Figs 1.2 and 2.2)

Etymology: brevis $=$ short. Holotype: Fig. 1.2 derived from L. granatensis 45 . Material studied: L. granatensis 36, 45, 56, 58, and L. europaeus 60 and 68.

Size: $27 \times 14 \mu \mathrm{m}(23-31 \times 13-15) ; \mathrm{n}=10 ; \mathrm{SI}=1.93$.

Shape and colour: elongated or slightly kidney-shaped, of a very pale yellow.

Wall: thin and smooth with a flattened pole.

Micropyle: absent.

Sporocysts: these occupy the near totality of the volume of the oocyst, and are stocky, measuring $15 \times$ $8 \mu \mathrm{m}$, and sporozoites contain one small and one large elongated refractile body.

Residua: a round small OR of $4 \mu \mathrm{m}$ in diameter is present; a well limited SR with fine grains is present.

\section{Discussion}

Justification for a new sub-species has been presented above (see E. l. leporis).

The sub-species E. l. brevis could be compared to E. perforans (Leuckart, 1879) parasite of Oryctolagus by virtue of its elongated ellipsoid shape, its white colour, of the smooth oocyst wall, and of the presence of an OR and an SR. The two species are however distinguishable morphologically, E. perforans being smaller $(22.5 \times 13.9 \mu \mathrm{m} v s 27 \times 14 \mu \mathrm{m})$, and a micropyle, absent in E. l. brevis, is found occasionally in E. perforans (Pellérdy, 1974).

E. l. brevis was, so far, recorded from France and England only, the other authors from central or eastern europe, giving mensurations corresponding to E. l. leporis.

\section{3 - EIMERIA ORBICULATA LUCAS, LAROCHE \& DuRAND, 1959 (Figs 1.3 and 2.3)}

Material studied: L. granatensis 44, 45 (Fig. 1.3).

Size: $13 \times 13 \mu \mathrm{m}(12-16 \times 12-15) ; \mathrm{n}=12 ; \mathrm{SI}=1$.

Shape and colour: sub-spherical and white.

Wall: smooth, and most frequently with a semi-lunar gap between the internal and external walls.

Micropyle: absent.

Sporocysts: they occupy the whole space in the oocyst, measuring $9 \times 5 \mu \mathrm{m}$, and sporozoites possess two round refractile bodies.

Residua: a sharply defined irregular OR measuring $2 \mu \mathrm{m}$. No SR was seen.

\section{Discussion}

Three species of rounded parasites of small size are morphologically close. The species E. exigua Yakimoff, 1934, a parasite of the rabbit but not the hare, is easily distinguished by the presence of a well defined SR. Two species have been noted in hares: 1) E. hunga- 

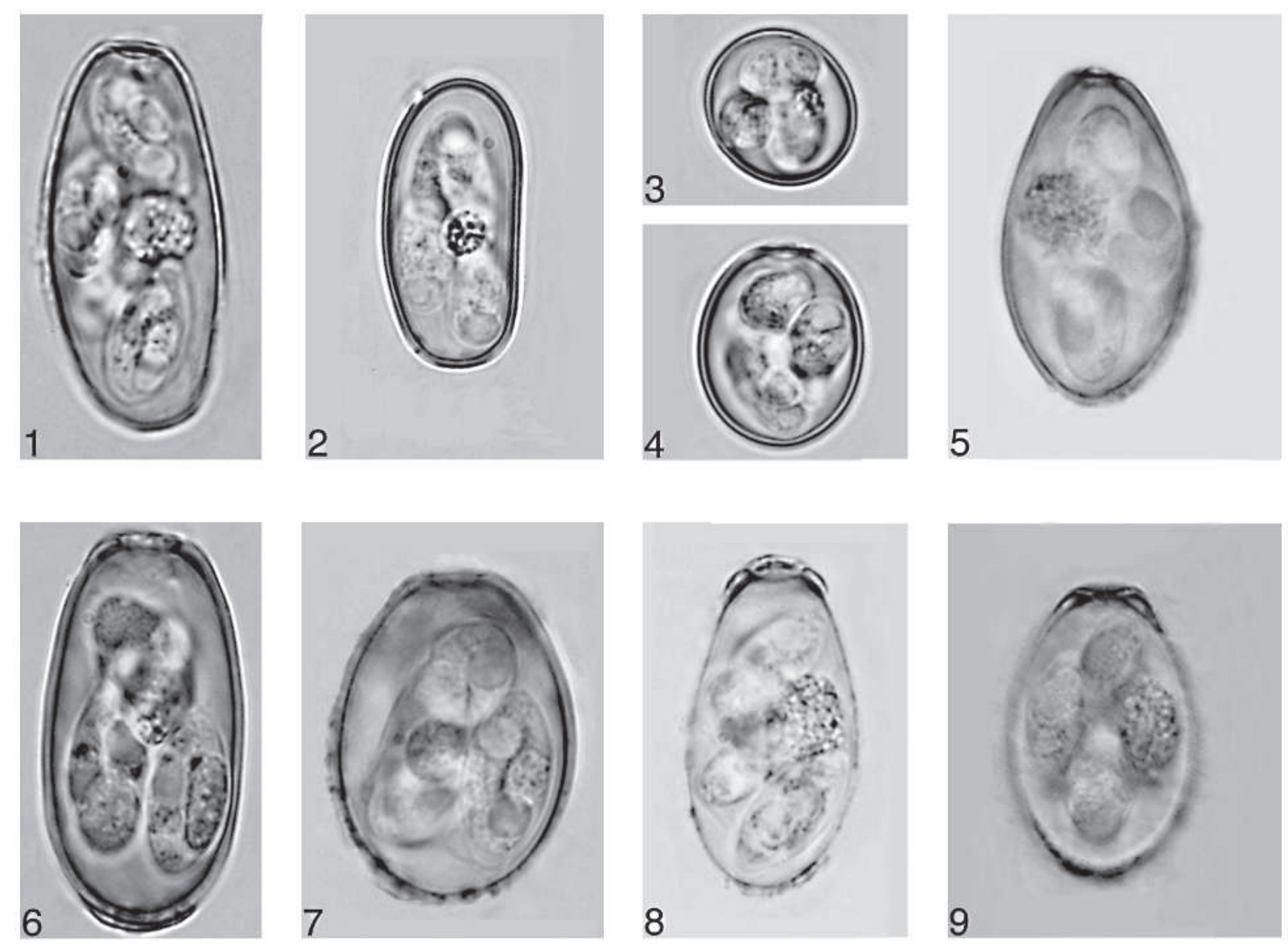

5
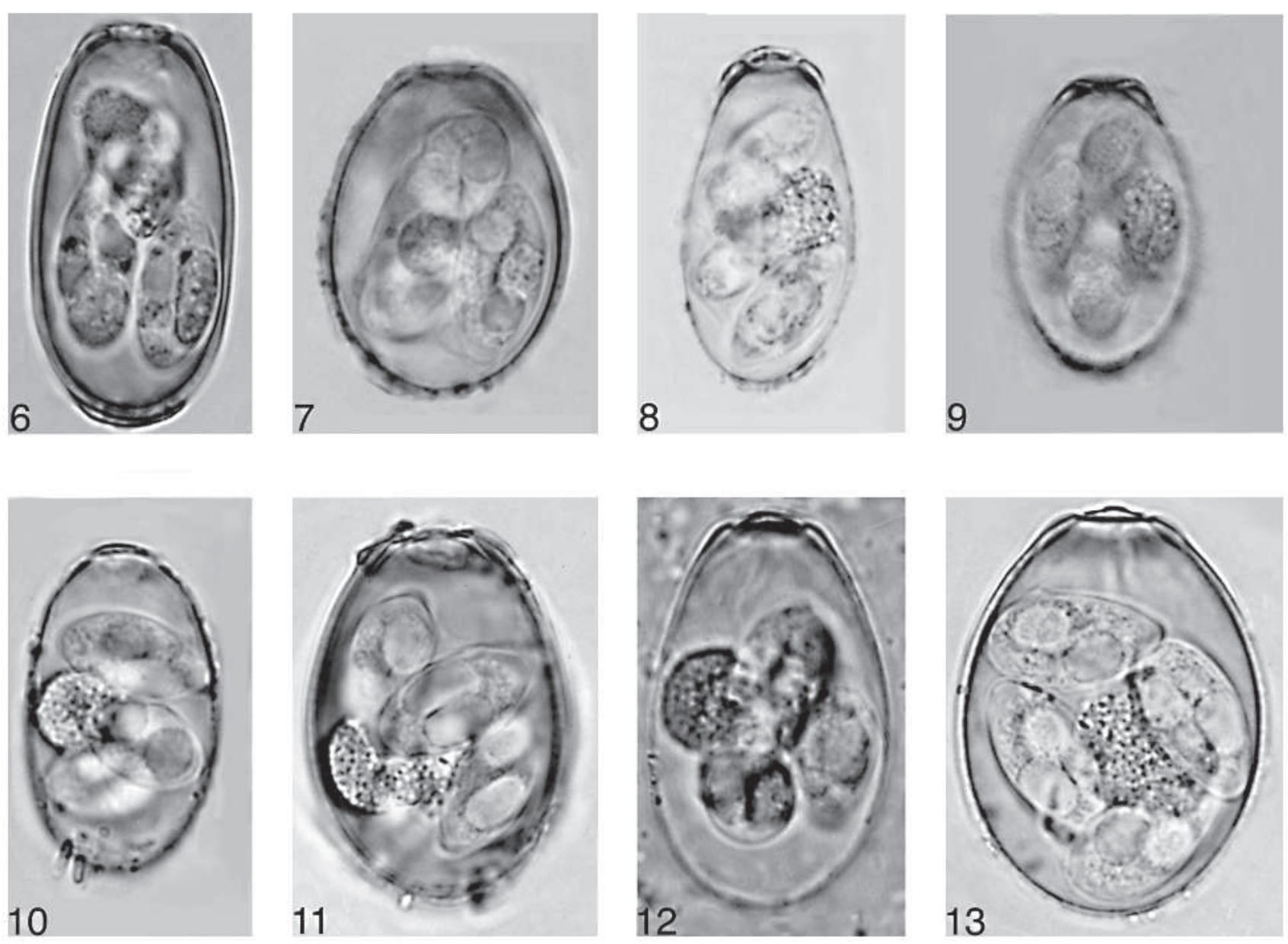

Fig. 1. - 1. Eimeria leporis leporis; 2. E. l. brevis; 3. E. orbiculata; 4. E. audubonii; 5. E. europaea; 6. E. nicolegerae; 7. E. gantieri; 8. E. deharoi deharoi; 9. E. d. rotonda; 10. E. bainae; 11. E. coquelinae; 12. E. gresae; 13. E. mazierae $(\times 1,320)$. 


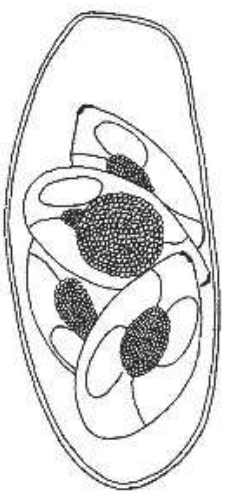

1

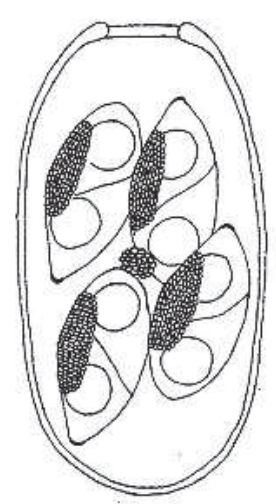

6

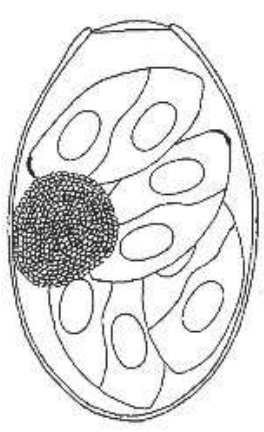

10

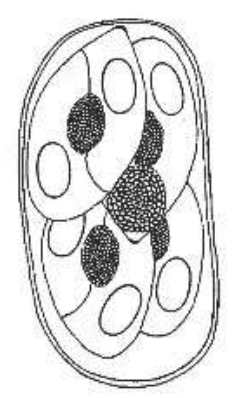

2

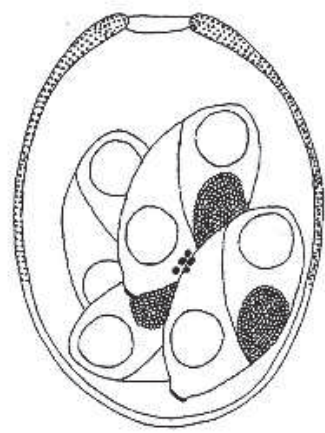

7

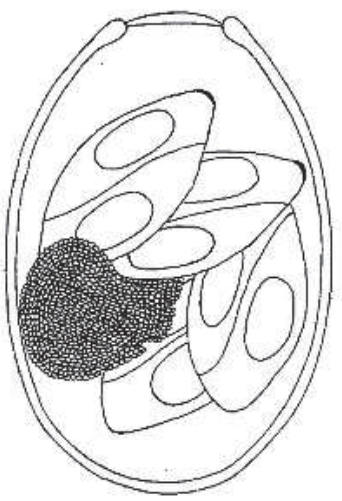

11

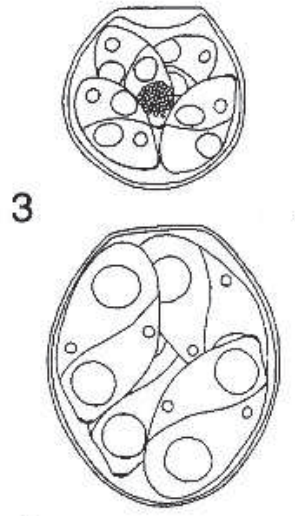

4

$10 \mu \mathrm{m}$

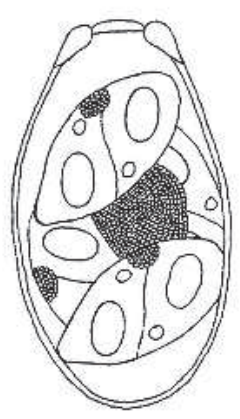

8

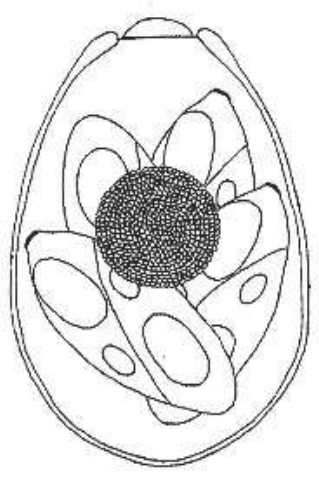

12

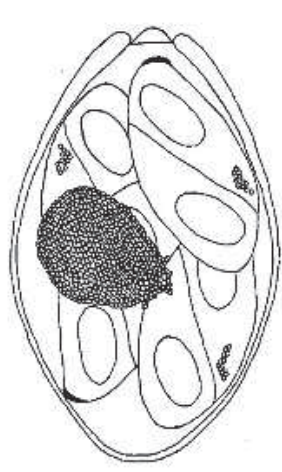

5

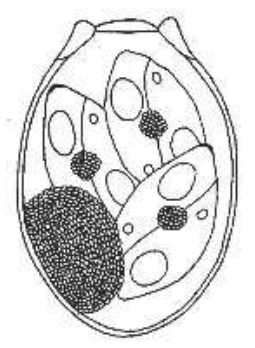

9

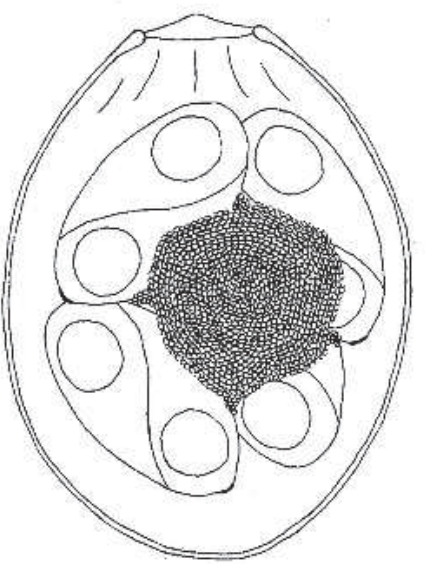

13

Fig. 2. - 1. Eimeria leporis leporis; 2. E. l. brevis; 3. E. orbiculata; 4. E. audubonii; 5. E. europaea; 6. E. nicolegerae; 7. E. gantieri; 8. E. deharoi deharoi; 9. E. d. rotonda; 10. E. bainae; 11. E. coquelinae; 12. E. gresae; 13. E. mazierae $(\times 1,290)$. 
rica, described in Hungary by Pellérdy (1956), has been found in India and western Europe by numerous researchers (see Levine \& Ivens, 1972). This parasite does not possess an SR and its OR is reduced to one to three granules. 2) E. orbiculata has been described by Lucas et al. in 1959 from French hares, at a time where they were not aware of the work of Pellérdy (1956) on E. hungarica. Bouvier considered this species as synonymous of E. hungarica. The taxon, however, does appear to be valid, since E. orbiculata was described as having a clearly visible rounded OR, as observed by us, and possibly in Italy by Tacconi et al. (1995) who indicated the presence of an OR and not of a few grains.

\section{4 - EIMERIA AUDUBONII DUSZYNSKI \&} MARQUARDT, 1969 (Figs 1.4 and 2.4)

Material studied: L. granatensis 6, 8, 44, 55 (Fig. 1.4) 56,58 .

Size: $21 \times 17 \mu \mathrm{m}(19-24 \times 14-18) ; \mathrm{n}=43$; SI $=1.24$. Shape and colour: ellipsoid and white.

Wall: outer envelope thin and smooth.

Micropyle: absent, but with a very slight flattening and thinning of the pole.

Sporocysts: $12 \times 7 \mu \mathrm{m}$ oval-shaped and stocky with a rounded extremity, they nearly fill the oocyst and sporozoites contain two refractile bodies, one small and one large.

Residua: both OR and SR are absent.

Discussion

None of the species described in Lepus is comparable, whether by size or morphology, to the parasites found by us. On the other hand, we have no morphological element that would allow to differentiate this parasite from E. audubonii Duszynski \& Marquardt, 1969, described in Sylvilagus auduboni (Baird, 1858) from Colorado.

It is doubtful that the species we have observed is indeed identical to that found in an American Sylvilagus, but morphological features that would allow to distinguish them are lacking. Moreover, we are aware that some Sylvilagus have been introduced in France by hunters on a number of occasions.

\section{5 - Eimeria EUROPAEA PelléRdy, 1956}

(Figs 1.5 and 2.5)

Material studied: L. europaeus 54 (Fig. 1.5).

Size: $31 \times 19 \mu \mathrm{m}(30-35 \times 17-21) ; \mathrm{n}=12 ; \mathrm{SI}=1.63$.

Shape and colour: oval and elongate, the anterior part narrower, brownish.

Wall: smooth, thickened around the micropyle.

Micropyle: present and formed by a dome of 3-5 $\mu \mathrm{m}$. Sporocysts: the available volume is nearly filled by the sporocysts of $19 \times 9 \mu \mathrm{m}$; sporozoites possess one elongated refractile bodies.
Residua: an OR of $9 \mu \mathrm{m}$ in diameter is present, and the SR is formed by a poorly defined aggregation of small granules.

Discussion

Pellérdy in 1956 clearly differentiates E. europaea from E. americana Carvalho, 1943, a parasite of L. townsendi campanius. The parasites found in our material conform to the original description. Differences in micropyle size, 6-9 $\mu \mathrm{m}$ for Pellérdy and 3-5 $\mu \mathrm{m}$ for us, are probably due to the manner in which the measurements were made, namely the external versus the internal diameter. This species, found frequently in Italy, has been found in only one of the hares we examined.

6 - Eimeria NICOLEGERAE N. SP. AOUTIL \& LANDAU (Figs 1.6 and 2.6)

Etymology: this species is dedicated to our colleague and friend Dr Nicole Léger.

Holotype: Fig. 1.6 from L. granatensis 24.

Material studied: L. granatensis 24, 42, 56 .

Size: $34 \times 18 \mu \mathrm{m}(28-40 \times 15-20) ; \mathrm{n}=11 ; \mathrm{SI}=1.89$.

Shape and colour: elongated ellipsoid with parallel edges, though in some cases one edge is more concave than the other brownish.

Wall: smooth and thick.

Micropyle: flat, thick, 5 to $6 \mu \mathrm{m}$ in diameter, with a micropyle ring that juts very slightly.

Sporocysts: these occupy two thirds of the oocyst volume, measure $15 \times 8 \mu \mathrm{m}$, and sporozoites possess a single round refractile body.

Residua: a very small OR is present ( $4 \mu \mathrm{m}$ in diameter), the SR is elongate with large regular grains.

\section{Discussion}

E. nicolegerae, by its size and shape, is close to E. coecicola Kheisin, 1947, parasite of Oryctolagus. The two species are ellipsoid, with an OR and an SR, have comparable sizes, a thick wall, and a flat micropyle. The notable differences are a small OR and an elongated SR for E. nicolegerae as opposed to a large OR and a rounded SR for E. coecicola.

Given the specific nature of hare coccidians, and the fact that they do not infect rabbits, we consider this parasite to be a new species that we name E. nicolegerae $\mathrm{n}$. sp.

Differences with $E$. cabareti are detailed in the discussion section for this species.

\section{7 - EIMERIA GANTIERI N. SP. AOUTIL \& LANDAU} (Figs 1.7 and 2.7)

Etymology: this species is dedicated to our colleague and friend Dr Jean-Charles Gantier.

Holotype: Fig. 1.7 from L. granatensis 45 .

Material studied: L. granatensis 45 . 
Size: $30 \times 22 \mu \mathrm{m}(29-33 \times 20-24) ; \mathrm{n}=4$; SI $=1.36$.

Shape and colour: ellipsoide to slightly oval, light brown.

Wall: two thirds of the external wall on the side of the micropyle are finely granular.

Micropyle: it measures $4 \mu \mathrm{m}$ with a thin straight upper part, and a concave base.

Sporocysts: they fill the available space, measure $16 \times$ $9 \mu \mathrm{m}$, and sporozoites contain a single refractile body. Residua: an OR is composed of a few small grains, and a compact oval SR is present.

Discussion

The ornate anterior half of the wall and the OR reduced to a few granules could evoke E. tailliezi but E. gantieri is distinct by its more roundish shape, its smaller size and by the fineness of its wall granules. The species is thus new, and we name it Eimeria gantieri n. sp.

8 - EIMERIA DEHAROI DEHAROI N. SP. AOUTIL \& LANDAU (Figs 1.8 and 2.8)

Etymology: this species is dedicated to our colleague and friend Dr Eric Deharo.

Holotype: Fig. 1.8 from L. granatensis 1.

Material studied: L. granatensis 1 .

Size: $28 \times 16 \mu \mathrm{m}(26-33 \times 14-18) ; \mathrm{n}=10 ; \mathrm{SI}=1.75$.

Shape and colour: ovoid and white with a yellowish micropyle ring.

Wall: smooth.

Micropyle: $4.5 \mu \mathrm{m}$ in diameter, micropyle ring $3 \mu \mathrm{m}$ high, made of a thickening of the external wall and giving the impression of being "accolé" to the oocyst wall.

Sporocysts: these have a very granular cytoplasm, measure $13 \times 7 \mu \mathrm{m}$, and sporozoites have two refractile bodies, one of which is large and elongate.

Residua: an OR of $7 \mu \mathrm{m}$ in diameter extending between the sporocysts is present, the SR is small and contains large dispersed grains.

Discussion

The closest species in the rabbit is E. media Kessel \& Jankiewicz (1931), that is characterized, as for E. deha$r o i$, by the presence of an OR and an SR, and whose dimensions are comparable $(31 \times 17 \mu \mathrm{m}$ rather than the $28 \times 16 \mu$ m we observed).

The two species can be easily distinguished, since the E. media micropyle and micropyle ring do not jut out appreciably. In the hare on the other hand, the micropyle is very noticeable and is surrounded by a marked micropyle ring.

This species is therefore new and we name it E. deharoi n. sp.

A sub-species is described below.
9 - EIMERIA DEHAROI ROTONDA N. SUBSP. AOUTIL \& LANDAU (Figs 1.9 and 2.9)

Etymology: rotonda $=$ rounded.

Holotype: Fig. 1.9 from L. granatensis 1.

Material studied: L. granatensis 1 .

Size: $23 \times 16 \mu \mathrm{m}(22-29 \times 13-18) ; \mathrm{n}=10 ; \mathrm{SI}=1.44$.

Shape and colour: short ellipsoid, pale yellow.

Wall, micropyle, sporocysts, and residua: same as those of E. deharoi deharoi.

\section{Discussion}

E. d. rotonda, though similar to E. d. deharoi, differs from it by its more rounded shape (SI $=1.44$ vs 1.75) and its distinctly smaller size $(23 \times 16 \mu \mathrm{m}$ vs $28 \times$ $16 \mu \mathrm{m})$. A histogram of oocyst lengths indicates two clearly defined peaks. As was the case for E. leporis, we suppose the presence of two subspecies whose localisation in the host and/or biological cycles are distinct. We name this parasites E. d. rotonda n. subsp.

\section{0 - EIMERIA BAINAE N. SP. AOUTIL \& LANDAU}

(Figs 1.10 and 2.10)

Etymology: this species is dedicated to our colleague and friend Dr Odile Bain.

Holotype: Fig. 1.10 from L. granatensis 20.

Material studied: L. granatensis 1, 20, 45, 56 .

Size: $29 \times 18 \mu \mathrm{m}(26-33 \times 15-21) ; \mathrm{n}=12 ; \mathrm{SI}=1.61$.

Shape and colour: ellipsoid and slightly elongate, yellowish-white.

Wall: smooth with a flattened pole at the micropylar end.

Micropyle: $6 \mu \mathrm{m}$ wide, slightly convex. Ring of a more sustained yellow tint.

Sporocysts: they occupy the whole volume of the oocyst, measure $15 \times 8 \mu \mathrm{m}$, and sporozoites have a single slightly oval refractile body.

Residua: round OR of $8 \mu \mathrm{m}$ in diameter with medium grains. No SR.

\section{Discussion}

This species can be distinguished from others, with white oocysts found in hares, by the presence of a micropyle, absent in E. leporis, by a size of $29 \mu \mathrm{m}$, largely superior to that of E. audubonii, by the ellipsoid shape and the absence of an SR, distinguishing it from E. deharoi. The species morphologically the closest, through colour dimensions and the presence of an OR and the absence of an SR, is E. honessi Carvalho, 1943, a parasite of different North American Sylvilagus, though that species is more ovoid and the one we describe is nearly totally ellipsoid. This species is thus new and we name it E. bainae n. sp. 
11 - EIMERIA COQUELINAE N. SP. AOUTIL \& LANDAU (Figs 1.11 and 2.11)

Etymology: this species is dedicated to our colleague and friend Dr Fabienne Coquelin.

Holotype: Fig. 1.11 from Lepus europaeus 17.

Material studied: L. granatensis 11, 52, and L. europaeus 17,54 .

Size: $35 \times 23 \mu \mathrm{m}(32-39 \times 20-26) ; \mathrm{n}=32 ; \mathrm{SI}=1.52$. Shape and colour: short ellipsoid, brownish.

Wall: thick external wall that is finely granular, though this is only visible after the oocyst has burst.

Micropyle: present, thin and little humped, surrounded by a simple thickening of the surface without a true micropyle ring, and measures 7 to $8 \mu \mathrm{m}$.

Sporocysts: they measure $19 \times 9 \mu \mathrm{m}$, fill $2 / 3$ of the oocyst, and sporozoites possess a single large and elongate refractile body.

Residua: a well limited but of irregular contour OR of $11 \mu \mathrm{m}$ in diameter with medium grains is present. No SR.

\section{Discussion}

Of all the material we examined, this species was the closest to the one wrongly referred to by most authors as E. robertsoni Madsen, 1938.

E. magna var. robertsoni has been described by Madsen in 1938 from L. arcticus groenlandicus, captured in Greenland. It is of ellipsoid shape and measures $42.71 \times 25.84 \mu \mathrm{m}$, and the sporocysts are $17-22 \times 7$ $8 \mu \mathrm{m}$ in size. Carvalho (1943) used the name E. robertsoni that he elevated to the species level for a parasite species found in L. townsendi campanius Hollister, 1915 from Iowa. This identification seems doubtful to us since Carvalho (1943) equates both E. magna var. robertsoni (Fig. 6.a of Madsen) and E. perforans var. groenlandica (Fig. 5.b of Madsen). However, these two coccidians can be distinguished by their size, shape, the OR and the micropyle.

Pellérdy in 1956, equates to the species of Carvalho (1943), an Eimeria parasite found in Hungarian L. europaeus, which seems difficult to admit, since the species of Pellérdy is narrowed in its anterior end. In 1967, Bouvier, who appears to have found the species of Pellérdy in Switzerland, indicated that it was a parasite of the caecum, while the American species is found located in the duodenum. Thus, we think that the name "robertsoni" which appears to refer to three different species, should be abandoned.

The oocysts we describe from our specimens belong to a new species with characteristic size and shape. Indeed, this coccidian can be distinguished from the Greenland species, which is significantly more rounded, and from the Hungarian and Iowa species which are both larger and narrower. The characteristics that serve to differentiate this species from two des- cribed below (E. grease and E. reniai) are indicated in the respective sections.

The species is therefore new and we name it Eimeria coquelinae n. sp.

\section{2 - EIMERIA GRESAE N. SP. AOUTIL \& LANDAu}

(Figs 1.12 and 2.12)

Etymology: this species is dedicated to our colleague and friend Dr Virginie Grès.

Holotype: Fig. 1.12 from Lepus granatensis 20.

Material studied: L. granatensis 5, 8, 20, 35, 50, 55 and

L. europaeus $47,54,58$.

Size: $33 \times 22 \mu \mathrm{m}(28-39 \times 20-24) ; \mathrm{n}=61 ; \mathrm{SI}=1.5$.

Shape and colour: slightly ovoid, flattened at the micropyle end, light yellow.

Wall: smooth. Thickening of the wall around the micropyle forming a micropyle ring.

Micropyle: $8 \mu \mathrm{m}$ in diameter, with a straight base and a slightly bulging dome.

Sporocysts: elongate, $19 \times 8,5 \mu \mathrm{m}$ assembled in the centre, leaving a free space on both sides. Two refractile bodies, one small and the other large in the sporozoites.

Residua: a round OR measuring $9 \mu \mathrm{m}$ diameter formed by coarse granules, well limited and sending a few expansions between the sporocysts. No SR.

\section{Discussion}

In Lepus, the closest species is E. coquelinae, described above. The differences between the two species are as follows: E. coquelinae is ellipsoid and measures $35 \times$ $23 \mu \mathrm{m}$ while E. gresae is ovoid and measures $33 \times$ $22 \mu \mathrm{m}$, the micropyle is flat in E. coquelinae while convex in E. grease, and the external wall is thick and granular in E. coquelinae but smooth and thinner in E. gresae.

This species can be distinguished from the various species described under the name of robertsoni in the same way as in the discussion of E. coquelinae. Whilst the differences observed between it and the closely related E. reniai are discussed in the section devoted to this latter species.

In Oryctolagus, the closest species is E. magna Pérard, 1925. Apart from the presence of an SR, E. magna displays characteristics intermediary between E. gresae and E. coquelinae, namely its shape and size correspond with those of E. coquelinae but it smooth wall corresponds to that of E. gresae.

This species of the hare is therefore, new and we name it E. gresae n. sp.

\section{3 - EIMERIA MAZIERAE N. SP. AOUTIL \& LANDAU}

(Figs 1.13 and 2.13)

Etymology: this species is dedicated to our colleague and friend Dr Dominique Mazier. 
Holotype: Fig. 1.13 from Lepus granatensis 8.

Material studied: L. granatensis 8, 20.

Size: $40 \times 29 \mu \mathrm{m}(39-41 \times 29-31) ; \mathrm{n}=2 ; \mathrm{SI}=1.38$.

Shape and colour: oval and very large, light yellow. Wall: thin and smooth wall.

Micropyle: $8 \mu \mathrm{m}$ in diameter, pyramidal in shape and surrounded by a slight thickening of the wall.

Sporocysts: they measure $18 \times 10 \mu \mathrm{m}$; sporozoites possess one round refractile bodies and occupy $3 / 4$ of the available oocyst volume.

Residua: the OR is large, irregular and with diverticula, it harbours medium very diffuse and non-compacted grains, while an SR is absent.

\section{Discussion}

In view of it's large size, the presence of an OR and the absence of an SR, the only other coccidian to which it might be compared is that described by Madsen, in 1938, in Lepus arcticus groenlandicus Rhoads, 1896 under the name of E. magna var. robertsoni (Fig. 6.a). In our opinion, that species is one of Greenland and not Europe (see the discussion on E. coquelinae above). The parasite we describe differs from that of Madsen by its rounder shape and larger size $(40 \times 29 \mu \mathrm{m} v s$ $42.71 \times 25.84 \mu \mathrm{m})$, by the pyramidal non-straight shape of the micropyle, and by the shorter and thicker sporocysts.

Despite the small number of oocysts observed, of which two only have been measured, the characteristics of this species are quite distinctive and we consider it to be a new species that we name E. mazierae n. sp.

\section{4 - EIMERIA RENIAI N. SP. AOUTIL \& LANDAU}

(Figs 3.14 and 4.14)

Etymology: this species is dedicated to our colleague and friend Dr Laurent Rénia.

Holotype: Fig. 3.14 from Lepus granatensis 20.

Material studied: L. granatensis 2, 20, 49, 58 and L. europaeus 60.

Size: $37 \times 22 \mu \mathrm{m}(35-40 \times 19-24) ; \mathrm{n}=10 ; \mathrm{SI}=1.68$.

Shape and colour: elongate and ovoid with one side flatter than the other, brown.

Wall: smooth.

Micropyle: 4 to $5 \mu \mathrm{m}$ in diameter with a jutting dome, and well defined micropyle ring.

Sporocysts: they measure $19 \times 9 \mu \mathrm{m}$, and sporozoites have two refractile bodies, one elongate, and the other smaller and round. In the oocyst, they are surrounded by a large empty space on all sides.

Residua: an OR is present and measures $10 \mu \mathrm{m}$ in diameter, and SR is absent.

\section{Discussion}

This species should be compared to E. gresae and E. coquelinae. It is close to E. gresae with which it coexists in hares 20 and 58, though not in hare 2.
E. reniai is however, more elongate and narrowed at the anterior end, the micropyle ring is hardly visible and the wall is smooth rather than granular. E. reniai differs from E. coquelinae by its ovoid anteriorly narrowed shape as compared to ellipsoid, by a poorly defined micropyle ring as opposed to the well defined one in E. coquelinae, and by the reduced size of the micropyle $(4-5 \mu \mathrm{m}$ rather than 7-8 $\mu \mathrm{m})$.

The species is thus new and we name it E. reniai n. sp. It was seen by Pakandl (1990) in Czechoslovakia but identified as E. robertsoni.

\section{5 - EIMERIA PIERRECOUDERTI N. SP. AOUTIL \& LANDAU (Figs 3.15 and 4.15)}

Etymology: this species is dedicated to our colleague and friend Dr Pierre Coudert.

Holotype: Fig. 3.15 from Lepus granatensis 47.

Material studied: Lepus granatensis 47.

Size: $35 \times 24 \mu \mathrm{m}(33-37 \times 23-26) ; \mathrm{n}=12$; SI $=1.46$.

Shape and colour: slightly ovoid, brownish.

Wall: the anterior half of the external wall is evenly covered by protruding granules and is thicker than the posterior half.

Micropyle: $8 \mu \mathrm{m}$ in diameter, forming a slight dome. Sporocysts: they occupy $2 / 3$ of the oocyst, measure $21 \times 9.5 \mu \mathrm{m}$, and sporozoites possess a round refractile body.

Residua: an OR measuring $11 \mu \mathrm{m}$ in diameter is present, it has partially defined edges and some extensions are projected between the sporocysts. SR is absent.

\section{Discussion}

The granular anterior wall restricts the discussion to species with this feature, i.e. E. gantieri and species previously described under the name var. semisculpta by Madsen (1938) and E. semisculpta sensu Pellérdy (1956).

The taxon semisculpta is in our opinion invalid, since the type from Greenland differs from that of Hungary by its size and the presence of OR in the former but not in the latter. Thus validity of elevating the form "semisculpta" to species rank cannot be maintained. The size of $E$. pierrecouderti is distinctly inferior to that of the species described by Pellérdy \& Madsen. It can, moreover, be easily distinguished from the species of Pellérdy by its large compact $O R$, and from that of Madsen by its much shorter and stockier sporocysts.

E. pierrecouderti differs from E. gantieri by its larger size, by the coarser granulations of the wall and by the presence of a conspicuous OR, reduced to a few small grains in E. gantieri.

This species is thus new and we name it E. pierrecouderti n. sp. 

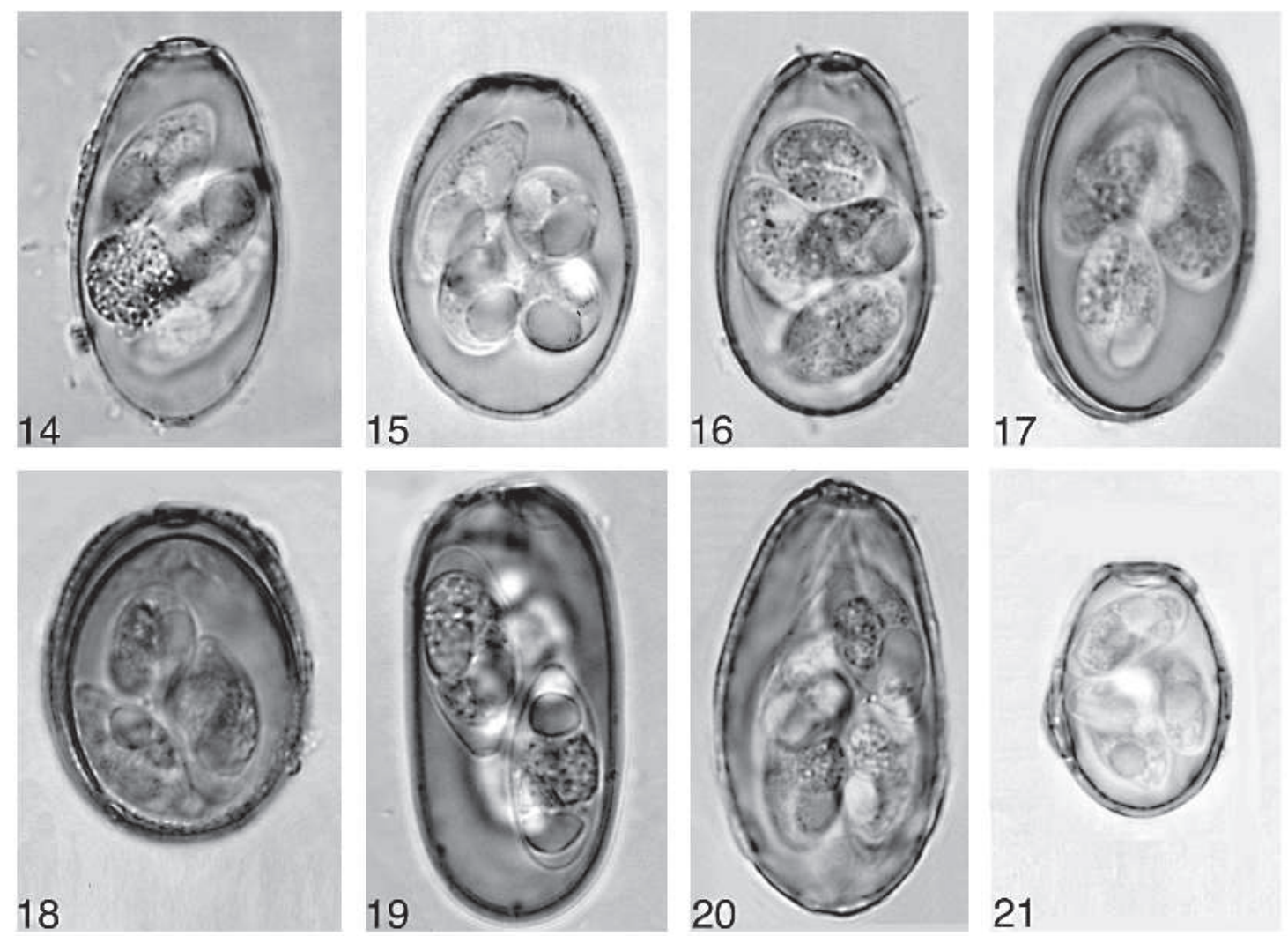

Fig. 3. - 14. E. reniai; 15. E. pierrecouderti; 16. E. cabareti; 17. E. stiedai; 18. E. lapierrei; 19. E. macrosculpta; 20. E. tailliezi; 21. E. babatica $(\times 1,320)$.

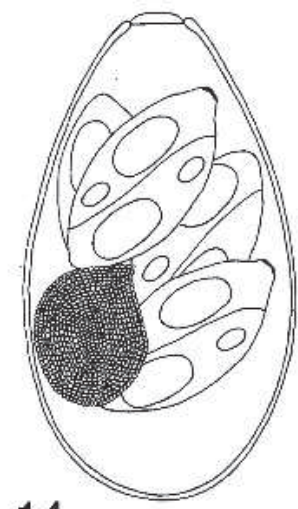

14

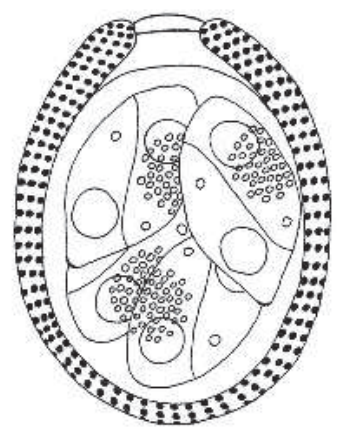

18

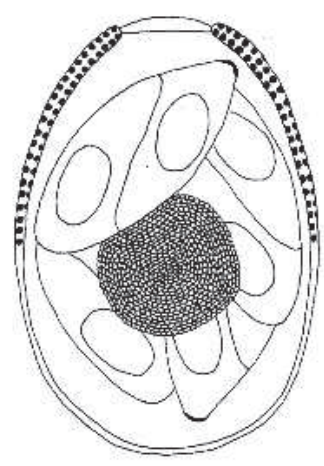

15

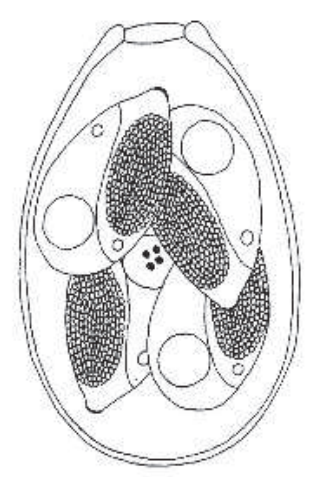

16

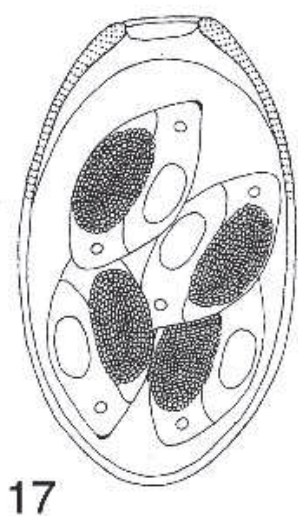

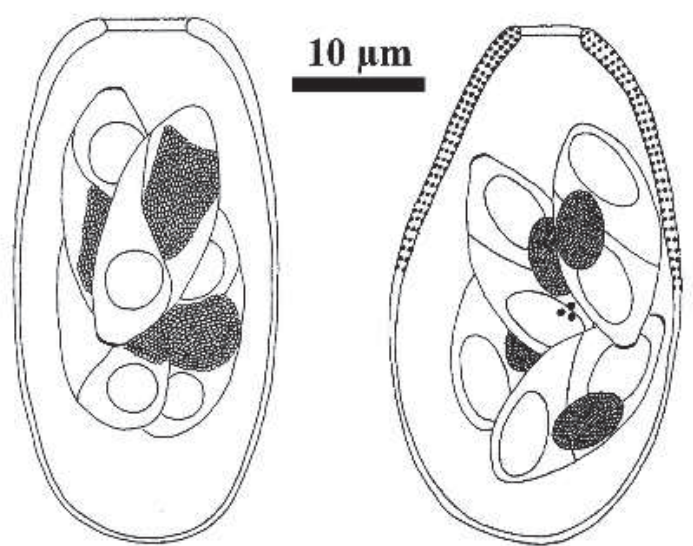

19
20

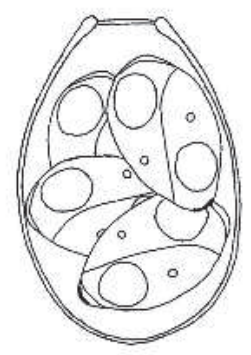

21

Fig. 4. - 14. E. reniai; 15. E. pierrecouderti; 16. E. cabareti; 17. E. stiedai; 18. E. lapierrei; 19. E. macrosculpta; 20. E. tailliezi; 21. E. babatica $(\times 1,290)$. 
16 - EIMERIA CABARETI N. SP. AOUTIL \& LANDAU

(Figs 3.16 and 4.16)

Etymology: this species is dedicated to our colleague and friend Dr Jacques Cabaret.

Holotype: Fig. 3.16 from Lepus granatensis 45.

Material studied: L. granatensis 38, 45, 56, 58 and

L. europaeus 60.

Size: $35 \times 22 \mu \mathrm{m}(32-38 \times 20-24) ; \mathrm{n}=32 ; \mathrm{SI}=1.59$.

Shape and colour: ovoid, light brown.

Wall: the external wall is smooth with a space frequently observed between the inner and outer walls. Micropyle: measures $5 \mu \mathrm{m}$ in diameter and is thick barely convex and slightly concave at the base. A micropyle ring is present.

Sporocysts: they measure $17 \times 9 \mu$ m occupy $2 / 3$ of the oocyst, and sporozoites possess two round refractile bodies, one large and one small.

Residua: an OR is formed by three to five grains. A large well defined oval-shaped SR with large grains is present.

\section{Discussion}

The species we describe can be compared to E. coecicola Kheisin, 1947, from Oryctolagus essentially by reason of its size, elongate shape, thick external wall, and the presence of a micropyle ring. It differs from this species by and OR reduced to 2-3 granules, that is large rounded and well-defined in E. coecicola, and by its elongated SR that is rounded in E. coecicola.

E. cabareti resembles E. stiedai by its size, thick wall, and the presence of a large SR. However, it differs from E. stiedai by its ovoid rather than ellipsoid shape, by the presence of a more marked micropyle and a jutting micropyle ring.

The species is thus new and we name it Eimeria cabareti n. sp.

It was seen by Pakandl (1990) in Cszechoslovakia but identified as E. townsendi, although it was noted that oocysts were much smaller than in previous descriptions.

\section{7 - EIMERIA STIEDAI (LINDEMANN, 1865)}

(Figs 3.17 and 4.17)

Material studied: Lepus europaeus 54 (Fig. 3.17), 60, 68 and L. granatensis 45 .

Size: $37 \times 22 \mu \mathrm{m}(33-40 \times 19-24) ; \mathrm{n}=62 . \mathrm{SI}=1.68$. Shape and colour: ellipsoid and in some cases one side more convex than the other, brownish.

Wall: thick external wall, with a more pronounced thickening and fine granulation at the anterior half. A space can sometimes be observed between the external and internal walls of the oocyst.

Micropyle: small, flat and measuring $4.5 \mu \mathrm{m}$, and in some cases with a depression visible in the thickening of the adjacent external wall.
Sporocysts: stocky, $18 \times 10 \mu \mathrm{m}$ in size, and occupy $2 / 3$ of the oocyst; sporozoites with one small and one larger refractile body.

Residua: an OR is absent or represented by a single grain. An oval-shaped SR is present, measures $9 \mu \mathrm{m}$ and has large grains.

\section{Discussion}

The species we describe from the hare is nearly identical to that we had observed in France in Oryctolagus (Grès et al., 2003). However, one minor difference can be observed between the parasites of the hare and the rabbit. For Bouvier, in Switzerland, as for us, the micropyle is quite distinct in the parasite from the hare while it is barely visible in that from the rabbit.

E. stiedai has also been recorded in spontaneous infections in different Sylvilagus (See Levine \& Ivens 1972) but the identity between E. stiedai of Oryctolagus, of Sylvilagus and that of Lepus is not established with certainty as yet.

\section{8 - EIMERIA LAPIERREI N. SP. AOUTIL \& LANDAU (Figs 3.18 and 4.18)}

Etymology: this species is dedicated to our colleague and friend Pr Jacques Lapierre.

Holotype: Fig. 3.18 from Lepus granatensis 45.

Material studied: Lepus granatensis 45 and L. europaeus 54.

Size: $33 \times 26 \mu \mathrm{m}(31-35 \times 24-28) ; \mathrm{n}=11 ; \mathrm{SI}=1.27$. Shape and colour: rounded oval, dark brown.

Wall: the external wall is thick and coarsely granular, separated under the micropyle from the underlying layer by an important space of approximately $2 \mu \mathrm{m}$. Micropyle: straight and thick, apparently continuous with the external wall and measuring $6 \mu \mathrm{m}$.

Sporocysts: these are stocky measuring $17 \times 9 \mu \mathrm{m}$ and sporozoites possess two round refractile bodies.

Residua: and OR is absent. An SR of $7 \times 4 \mu \mathrm{m}$ is present and is formed by large bunched granules that are not however, bound by a membrane.

\section{Discussion}

The species we describe should be compared to coccidias displaying a granular external ornamentation. Eimeria sculpta Madsen, 1938, parasite of Lepus arcticus groenlandicus in Greenland, is piriform, measures $37 \times 29 \mu \mathrm{m}$, and is characterised by a very small micropyle (ca. $2 \mu \mathrm{m})$ and by a very well defined ellipsoid SR. The species described under the same name by Carvalho (1943), a parasite of Lepus townsendi campanius in Iowa, measures $36 \times 29.7 \mu \mathrm{m}$ and is characterized by a large micropyle $(7.5 \mu \mathrm{m})$ and an SR of ill-defined shape.

The species we have observed is rounded ovoid rather than piriform and is smaller $(33 \times 26 \mu \mathrm{m})$. The SR has a grossly rounded form. 
This species is thus new and we name it Eimeria lapierrei $\mathrm{n}$. sp.

It was probably seen by Pakandl (1990) but identified by this author as E. sculpta.

\section{9 - EIMERIA MACROSCULPTA SUGAR, 1979}

(Figs 3.19 and 4.19)

Material studied: L. granatensis 1, 11, 24, 57, 58. Size: $42 \times 21 \mu \mathrm{m}(40-45 \times 18-22) ; \mathrm{n}=19 ; \mathrm{SI}=2$. Shape and colour: elongate and ellipsoid with parallel edges. One extremity is rounded while the other, the micropyle end, is slightly flattened. The colour is brownish.

Wall: thicker and darker at the anterior half.

Micropyle: flat, $6.5 \mu \mathrm{m}$ wide with no definite ring. Sporocysts: they occupy approximately $60 \%$ of the oocyst volume, long $(22 \times 8.5 \mu \mathrm{m})$ with rounded ends. One large, elongate refractile body is observed per sporozoite.

Residua: no OR. A large, ellipsoid and well defined SR with medium sized granules.

\section{Discussion}

This species should be differentiated from brown, elongate, ellipsoid coccidia lacking an OR but with large well-defined SR.

E. stiedai is smaller $(38 \times 22.5 \mu \mathrm{m}$; SI $=1.85) v s(42 \times$ $21 \mu \mathrm{m}$; SI = 2) E. macrosculpta, has straight edges, while those of E. stiedai are slightly curved; also the sporocysts we describe are longer $(22 \times 9 \mu \mathrm{m})$ than those of E. stiedai $(18 \times 10 \mu \mathrm{m})$.

E. neoleporis Carvalho, 1942, a parasite of Sylvilagus floridanus mearnsii (Allen, 1894), in Iowa, differs from E. macrosculpta by its size $(42 \times 21 \mu \mathrm{m}$ as compared to $38.8 \times 19.8 \mu \mathrm{m}$ for E. neoleporis), by its colour, pinkish yellow, not brown and by its domed micropyle, flat in E. macrosculpta. The sporocysts of E. macrosculpta are longer $(22 \times 9 \mu \mathrm{m})$ than those of E. neoleporis $(17 \times 8.5 \mu \mathrm{m})$.

E. roobroucki Grès, 2002, is a parasite of wild rabbits in France. E. macrosculpta is much smaller than E. roobroucki $(42 \times 22 \mu \mathrm{m}$ instead of $55 \times 34 \mu \mathrm{m})$; SI $=2$ instead of 1.63 .

Our description differs only slightly from that of E. macrosculpta by Sugar (1979); our parasite is slighly smaller (mean $42 \times 21 \mu \mathrm{m}$ vs $46 \times 26 \mu \mathrm{m}$ for E. macrosculpta) but in all other respects seems identical.

The species was also seen by Pakandl who gives slightly smaller dimensions: $41,7 \times 23,6 \mu \mathrm{m}$.

\section{0 - EIMERIA TAILLIEZI N. SP. AOUTIL \& LANDAU}

(Figs 3.20 and 4.20)

Etymology: this species is dedicated to our colleague and friend Dr Roger Tailliez.

Holotype: Fig. 3.20 from Lepus europaeus 60.

Material studied: Lepus europaeus 60.
Size: $42 \times 23 \mu \mathrm{m}(40-43.5 \times 22-24.3) ; \mathrm{n}=8$; $\mathrm{SI}=1.81$. Shape and colour: elongate and ovoid, often asymmetric, with one edge slightly concave and the other more convex, brownish.

Wall: the anterior half is thicker and darker than the posterior half and shows coarse granulations.

Micropyle: flat and $6 \mu \mathrm{m}$ large.

Sporocysts: they occupy $2 / 3$ of the oocyst, measure $19 \times 9 \mu \mathrm{m}$, and sporozoites possess an oval-shaped refractile body.

Residua: an OR is reduced to two or three grains, while an elongated compact SR of $6 \mu \mathrm{m}$ displays quite fine grains.

\section{Discussion}

The sole species, that is close to E. tailliezi by its size and shape, is E. neoleporis Carvalho, 1942, from Sylvilagus floridanus mearnsii Allen in Iowa.

E. neoleporis is ellipsoid, elongated or subcylindrical, and measures $38 . \times 19.8 \mu \mathrm{m} ; \mathrm{SI}=1.95$, while E. tailliezi is ovoid and larger $(42 \times 23 \mu \mathrm{m}$; SI $=1.81)$.

The species we describe could be compared to the coccidian identified as E. townsendi by Brillard (1984), since the elongate ovoid form and the oocyst size $(41 \times$ $21 \mu \mathrm{m}$ ) depicted on Photo 4, correspond to our species. The name townsendi appears for the first time in the article of Carvalho (1943) as E. magna forma townsendi of L. townsendi campanius, from Iowa.

Pellérdy in 1956, employs this name for a parasite species of a Hungarian, L. europaeus, where the oocyst differs from that described by Carvalho. Indeed, it is characterized by the presence of a poorly defined SR and by the absence of an OR, whereas the form townsendi depicted by Carvalho possesses well-defined OR and SR.

After Pellérdy (1956), many authors in western Europe, including Bouvier (1967) and Tacconi et al. (1995), have provided illustrations of such parasites. Here again, the oocysts shown do not correspond to the original description of Carvalho (1943) since they are devoid of an OR.

The taxon E. townsendi must, therefore, be abandoned. The species we describe is new and we name it Eimeria tailliezi n. sp.

It was seen by Pakandl (1990) but identified by this author to as E. semisculpta.

\section{1 - EIMERIA BABATICA Sugar, 1978}

(Figs 3.21 and 4.21)

Material studied: Lepus granatensis 2, 3, 5, 6, 8, 38, 44, $56,58$.

Size: $26 \times 17.5 \mu \mathrm{m}(23-29 \times 15-18) ; \mathrm{n}=35$; SI $=1.49$. Shape and colour: ovoid, nearly white and tinged with yellow-brown around the micropyle.

Wall: smooth and thin.

Micropyle: straight, measuring $4.5 \mu \mathrm{m}$ in diameter, surrounded by a ring that appears stuck to the oocyst. 
Sporocysts: they are stocky and measure $15 \times 8 \mu \mathrm{m}$, fill the whole volume of the oocyst and sporozoites possess a round refractile body

Residua: both OR and SR are absent.

\section{Discussion}

Our parasite differs slighly from the original description: micropyle smaller $(4.5 \mu \mathrm{m}$ instead of $6-8 \mu \mathrm{m})$ and by the absence of an SR.

The closest species, by its size, absence of OR and SR and the presence of a micropyle is E. septentrionalis Yakimoff, Matschoulsky \& Spartansky, 1936, in Lepus timidus Linnaeus, from Murmansk (Russia).

$E$. babatica differs from $E$. septentrionalis by its ovoid form, as opposed to rounded ( $\mathrm{SI}=1.49$ vs 1.2 ), by the small size of the micropyle ( $4.5 \mu \mathrm{m} v s$ more than $9 \mu \mathrm{m}$ as measured from the drawing of the original) and the less conspicuous ring.

\section{DISCUSSION}

\section{ANALYSIS OF THE OBSERVATIONS}

T The Eimeria of the Lagomorphs form a homogenous fauna. Nonetheless, different authors (including Levine \& Ivens, 1972) note strict specificity as characteristic. Oryctolagus cannot be infected experimentally with the parasites found in Lepus and only very rarely by those found in Sylvilagus.

We have noted through numerous examinations spanning seven months, that the fine morphological characters that distinguish the species one from another are quite constant. It was also the case with the rabbit coccidia studied by Grès for her thesis (personnal observations). Thus, we are of the opinion that the intra-specific variability is low and that the extent of geographical speciation has been grossly underestimated, particularly concerning hares which are mostly solitary animals. One may assume that their parasites are subject to rapid speciations

The parasite species found in Lepus, Sylvilagus and Oryctolagus are distinct though they are morphologically closely related. However the characteristics of the parasitic equilibriums are more clearly defined.

\section{- In Lepus}

The number of species in Lepus is considerable. We have noted 21 during the course of this study, and of these, seven were only observed in a single hare. It is thus likely that other species remain to be found. After concentration of the parasites in the faeces the total prevalence, in 2003, a particularly warm and dry year, was $53 \%$ (34 of the 64 hares examined were positive). Lower numbers are quoted by Bouvier (1967) in Switzerland, though he did not appear to have employed any methods to enrich the material. He noted that six of the 60 hares
(10\%) collected during a dry year were infected, 12 out of $76(16 \%)$ collected during an average year, and 21 out of 101 (21\%) collected during a wet year.

The species prevalence is by contrast very low. Two species E. gresae and E. babatica had a prevalence of $14 \%$, two others, E. audubonii and E. l. brevis of $9 \%$, and three species, E. reniai, E. cabareti and E. macrosculpta had a prevalence close to $8 \%$. The remaining species had lower prevalences.

The parasite loads were clearly very low, though these were only grossly estimated. For instance, for the 64 hares examined only six oocysts of E. mazierae were observed. The highest parasite load, observed in hare 36, was 20,000 oocysts per gram of faeces, a low figure when compared to the levels observed for infections in the rabbit.

\section{- In Oryctolagus}

The number of species is low. 12 species were recorded, 10 of which were observed in France by Grès et al. (2003) who examined 254 rabbits. All the rabbits were infected thus the prevalence was $100 \%$.

The species prevalence was relatively stable, and neared $100 \%$ for the dominant species (E. perforans, $E$. flavescens and E. media) but did not exceed $4 \%$ for the less dominant ones.

The parasite load varied with the season and the age of the animals, and could reach very high levels such as 167,000 oocysts per gram of faeces.

- In Sylvilagus, the number of species enumerated by Levine \& Ivens in 1972 was 11, but this host has been less well studied than Oryctolagus, and the actual number is most probably higher. Overall prevalence was investigated by Duszynski \& Marquardt (1969) in Sylvilagus auduboni in Iowa, and was found to be $100 \%$, while specific prevalence for the six species lay between $22 \%$ to $90 \%$.

\section{PARASITE EQUILIBRIUM IN THE LAgOMORPhS}

Infection of a host by different species of the same genus is frequent. Chabaud \& Durette-Desset (1978) distinguished two types: populations in a state of stable equilibrium, composed of numerous species, and populations that vary from one host to the other but where the number of species are less numerous.

The Eimeria of Lagomorphs could not be assigned to either of these categories. In Oryctolagus, we observed a relatively stable limited number of species in that the prevalence is constant from one region to the other and during the course of a year (Grès et al. 2003). The parasite equilibrium in Lepus is opposite to that of Oryctolagus since the number of congeneric species is high but the prevalence and parasite loads are highly variable. The features of parasitism in Sylvilagus appear to us to be intermediary to those in Oryctolagus and in Lepus. 
Many factors can be invoked to explain these distinct patterns. Foremost is the gregarious behaviour of Oryctolagus that contrasts with the solitary behaviour of Lepus. The behaviour of Sylvilagus could be considered as intermediary.

In general, when the equilibriums are stable, the species are close to each other. In a given host the species are closer to each other than those found in a related but different host species. Thus, it was suggested that the parasite picture was reached by successive speciations from a single initial parasite species.

By contrast, the genus Eimeria, encompasses all coccidia that have an oocyst containing four sporocysts each of which harbours two sporozoites. This grouping made for its convenience, coincidentally gathered many species that are most probably polyphyletic.

\section{ORIGIN OF THE FAUNA}

"The geological range of this family (Leporidae) is the late Eocene to recent in North America, the late Oligocene to recent in Europe, the Oligocene, and Pliocene in Asia, and the Palaeocene to recent in Africa and South America." (Walker, 1968). The rabbit Oryctolagus cuniculus is a particular species that, until a very recent date (the Middle ages, fide Francis Petter), remained confined to western Europe and North Africa. In all probability, the parasite fauna in Lepus is at the origin of that in Oryctolagus. We can then suggest that the fauna of hares became progressively enriched through various introductions rather than through speciation from an initial species.

\section{ACKNOWLEDGEMENTS}

W e are gratefull to the presidents of hunting societies of the Fédération départementale des chasseurs des Pyrénées-Orientales for collecting material from hares, and we acknowledge particularly the help of M. Olivier Galaup.

\section{REFERENCES}

Bouvier G. Les Coccidies rencontrées en Suisse chez le lièvre gris (Lepus europaeus). Annales de Parasitologie Humaine et Comparée, 1967, 42, 551-559.

Brillard P.J.L. Coccidies et coccidioses intestinales du Lièvre Européen (Lepus europaeus P.). Thèse vétérinaire. Paris, École Nationale Vétérinaire d'Alfort, 1984.

Carvalho J.C.M. Eimeria neoleporis n. sp. occurring naturally in the cottontail and transmissible to the tame rabbit. Iowa State Coll. Journal Sci., 1942, 409-410.

Carvalho J.C.M. The coccidia of Wild Rabbits of Iowa. I. Taxonomy and host-specificity. Iowa State Coll. Journal Sci., 1943, 18, 103-135.
Chabaud A.G. \& Durette-Desset M.C. Parasitisme par plusieurs espèces congénériques. Bulletin de la Société Zoologique de France, 1978, 103, 459-464.

Coudert P., Licois D. \& Drouet-Viard F. Eimeria species and strains of rabbit, in: Biotechnology guidelines on techniques in coccidiosis research. Office for official publications of the European communities Press, 1995, 114-116.

Duszynski D.W. \& MARQuARDT W.C. Eimeria (Protozoa: Eimeriidae) of the Cottontail Rabbit Sylvilagus audubonii in the Northeastern Colorado, with Descriptions of three new species. Journal of Protozoology, 1969, 16, 128-137.

Grès V. La coccidiose des lapins de garenne en France. Thèse de parasitologie. Paris, Université Paris XII, 2001.

Grès V., Voza T., Chabaud A. \& Landau I. Coccidiosis of the wild rabbit (Oryctolagus cuniculus) in France. Parasite, 2003, 10, 51-57.

Honess R.F. The coccidia infesting the Cottontail Rabbit, Sylvilagus nuttallii grangeri (Allen), with descriptions of two new species. Parasitology, 1939, 31, 281-284.

Levine N.D. \& Ivens V. Coccidia of Leporidae. Journal of Protozoology, 1972, 19, 572-581.

Lucas A., LaRoche M \& Durand J. Les agents de la Coccidiose du Lièvre en France. Recueil de Médecine Vétérinaire, 1959, 135, 305-310.

MADSEN H. The Coccidia of the east Greenland hares (with a revision of the coccidia of hares and rabbits). Meddelser om Gronland 1938, 116, 1-38.

Nieschulz O. Ueber Hasenkokzidien (Eimeria leporis n. sp.). Deutsche Tierärztliche Wochenschrift, 1923, 31, 245-247.

PAKANDL M. Some remarks on the prevalence and species composition of hare coccidia. Folia Parasitologica, 1990, 37, 35-42.

PELLÉRDY L.P. On the status of the Eimeria species of Lepus europaeus and related species. Acta Veterinaria Academiae Scientiarum Hungaricae, 1956, 4, 450-467.

Pellérdy L.P. Coccidia and Coccidiosis. Verlag Paul Parey, Berlin und Hamburg, 1974.

ROBERTSON A. Coccidiosis of the hare. The Journal of Tropical Medicine and Hygiene, 1933, 36, 143-148.

SugAR L. Eimeria babatica sp. n. (Protozoa: Coccidia) from European hare (Lepus europaeus Pallas) in Hungary. Parasit. Hung., 1978, 11, 13-15.

SugAR L. Eimeria macrosculpta sp. n. (Protozoa, Coccidia) from European hare (Lepus europaeus Pallas) in Hungary. Parasit. Hung. 1979, 12, 9-10.

Tacconi G., Piergili-Fioretti D., Moretti A., Nobilini N. \& PasQuali P. Coccidia in Hare (Lepus europaeus) Reared in Umbria, Italy: Bioepidemiological study. Journal of Protozoology Research, 1995, 5, 77-85.

WALKER E.P. In: Mammals of the world Second Edition, Revised by Paradiso J.L, 1968. The Johns Hopkins Press, Baltimore, $1478 \mathrm{p}$.

Webster Ninth Collegiate Dictionnary. Merriam-Webster Inc publishers, 1985, Springfield, Massachssetts, USA, 1563 p.

Reçu le 27 octobre 2004 Accepté le 19 janvier 2005 